\title{
PERCEIVED IMPACT OF CANCER AMONG ADOLESCENTS AND YOUNG ADULTS: RELATIONSHIP WITH HEALTH-RELATED QUALITY OF LIFE AND DISTRESS
}

\author{
Husson $\mathrm{O}^{1}$, Zebrack $\mathrm{B}^{2}$ \\ ${ }^{1}$ Radboud University Medical Center, Department of Medical Psychology, Nijmegen, The \\ Netherlands \\ ${ }^{2}$ University of Michigan School of Social Work, Ann Arbor, MI, United States \\ Address for correspondence: \\ Olga Husson PhD \\ Radboud University Medical Centre \\ PO Box 9101, 6500 HB Nijmegen \\ The Netherlands \\ Olga.Husson@radboudumc.nl \\ Phone:+3124 3616361
}

This is the author manuscript accepted for publication and has undergone full peer review but has not been through the copyediting, typesetting, pagination and proofreading process, which may lead to differences between this version and the Version of Record. Please cite this article as doi: $10.1002 /$ pon.4300

This article is protected by copyright. All rights reserved. 


\begin{abstract}
Objective: To examine whether perceptions of the impact of cancer are related to healthrelated quality of life (HRQoL) and psychological distress among survivors of cancer in adolescence and young adulthood (AYA).
\end{abstract}

Methods: 173 AYA cancer survivors (aged 18-35 years and 15-29 years at time of diagnosis) completed a mailed survey assessing impact of cancer (IOC-AYA), HRQoL (SF-36), and distress (BSI-18). Hierarchical linear regression models analyzed the independent effects of perceived impacts of cancer on HRQoL and distress after controlling for clinical and sociodemographic characteristics. Multivariate analyses also examined the extent to which positive and negative perceptions attenuated the effects of control variables on HRQoL and distress. Results: Being unemployed or not in school, and self-reported health problems were significantly associated with worse physical HRQoL. Mental HRQoL and psychological distress appeared as a function of reporting both positive and negative impacts of cancer; mental health outcomes were better in AYAs reporting more positive and less negative impact of cancer in their lives. Perceived impact of cancer, in both positive and negative ways, attenuated the effects of sociodemographic and clinical factors on mental HRQoL and psychological distress.

Conclusion: Results suggest that mental HRQoL and psychological distress, but not physical HRQoL, are a function of survivors' perceptions of how cancer has affected them and continues to affect them in both positive and negative ways. Findings suggest that opportunities for AYA cancer survivors to re-frame or better understand the context of cancer in their lives may result in improved mental health outcomes. 
Keywords: impact of cancer; cancer; adolescent and young adult; quality of life; psychological distress; oncology

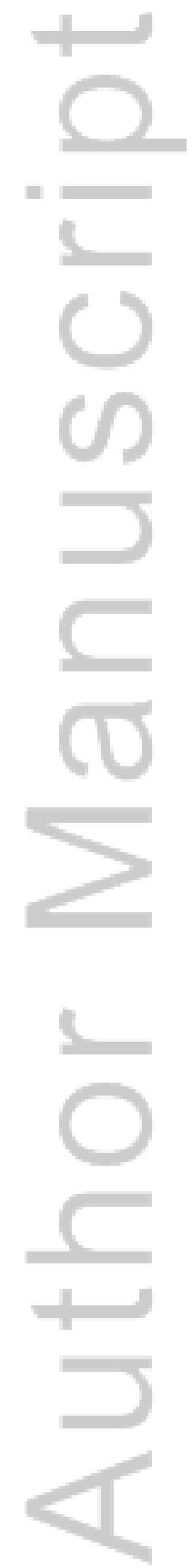

This article is protected by copyright. All rights reserved. 


\section{Introduction}

Adolescents and young adults (AYAs), aged 15-39 years, are in a challenging phase of life marked by developmental transitions such as becoming independent from parents, completing education, pursuing gainful employment, dating and having children[1, 2]. A cancer diagnosis challenges AYAs' abilities to achieve these developmental milestones[3]. For example, changes in physical appearance resulting from treatment (e.g. weight changes or hair loss) can negatively impact body image (looking different than peers) and interfere with self-esteem (avoiding social contacts) and identity development[3, 4]. AYA cancer survivors frequently report concerns regarding sexuality and fertility issues[5, 6] and often experience a diminished feeling of autonomy as they are forced to become dependent on parents or partners[7]. Furthermore, cancer treatment and late effects can interfere with completing education and getting a job, and thus contributing to increased risk for financial burden[8].

Confronting the everyday challenges of life as an adolescent or young adult while also coping with a life-threatening disease frequently leads to distress and deleterious effects on one's physical, psychological, social, and spiritual well-being $[9,10]$. Our understanding of cancer's true impact on people, and AYAs in particular, is complemented by studies indicating that many if not most AYAs are resilient, adjust well to their cancer experience, and report personal growth as an outcome of their experience[11-13]. Taken together, this body of work suggests that one's subjective perception or appraisal of cancer's impact on life may be more salient predictors of health-related quality of life (HRQoL) than objective cancer-related characteristics such as cancer type and prognosis for survival[12]. 
Psychological theory and brain science suggests that perceptions are a function of a cognitive process in which individuals construct reality. People create and tell stories to themselves and to others to represent a particular phenomenon or experience. While the stories themselves may not reflect an objective truth, they are quite real in their consequences[14]. How one appraises an event is more telling than any externally-defined or objective characteristic that others may ascribe to that same event $[15,16]$. The evidence base supporting cognitive behavioral interventions with cancer patients is grounded in this notion of appraisal. Extant literature supports the use of cognitive and behavioral approaches to improve HRQoL and reduce psychological distress in cancer patients, often by eliciting patient stories about how cancer has impacted or continues to impact their lives and then assisting them in re-creating and re-telling those stories as a means of reducing or changing deleterious consequences[17].

The new AYA module of the Impact of Cancer instrument enables examination of the extent to which AYA cancer survivors' perceptions of the impact of cancer in their lives are related to HRQoL and psychological distress [18]. Pediatric and older adult versions of this instrument in research and clinical practice have helped to identify survivors at risk for psychological, social or behavioral problems related to having had cancer, as well as content areas around which these patients require attention as they move forward in their lives after cancer $[19,20]$. Insight into the relationship between perceived impact of cancer and HRQoL is needed to inform the development of psychosocial and supportive care interventions that minimize or prevent long-term deleterious effects of cancer but also promote positive 
adaptation, resilience, and success in confronting the physical, psychological, social, spiritual challenges faced by AYA cancer. Therefore, the aims of this study are to (1) assess the association between sociodemographic and clinical characteristics and AYA specific impact of cancer; (2) examine whether AYA survivors' reported perceptions of impact of cancer on their lives are related to HRQoL and psychological distress, after controlling for clinical and sociodemographic characteristics.

\section{Methods}

\section{Design, Procedure, and Participants}

A cross-sectional study was conducted among 551 AYA cancer survivors registered in the tumor registry of the University of Michigan Comprehensive Cancer Center. Study eligibility criteria included AYA cancer survivors who were 15-29 years old at time of diagnosis, 18-35 years old at time of study, no more than 10 years post-diagnosis, and diagnosis of one of the following invasive cancer types: Hodgkins lymphoma, non-Hodgkins lymphoma, leukemia, testicular cancer, soft tissue sarcomas, and bone tumors (i.e., Ewings, Osteosarcoma). These cancers comprise $41 \%$ of all invasive cancers in the 15-29 year old age range[21]. All eligible respondents received survey questionnaires, informed consent forms, and a self-addressed and stamped return envelope via US mail. All procedures were approved by the University of Michigan Comprehensive Cancer Center Institutional Review Board.

\section{Measures}

This article is protected by copyright. All rights reserved. 
Impact of Cancer - Adolescent and Young Adult (IOC-AYA) version

The 31-item IOC-AYA was used to measure positive and negative impact of cancer among AYA cancer survivors. Details regarding the development, psychometric evaluation and scaling of the IOC modules are reported elsewhere[18-20]. Seven subscales represent distinct AYA survivor-specific content (Social Life; Uncertainties, Worries and Wonders; Cognitive Function; Sense of Purpose/Life Goals; Identity; Health Behaviors; and Health Literacy). For each item, respondents endorsed the perceived impact of cancer along a five-point Likert scale $(0=$ strongly disagree; $1=$ disagree; $2=$ neither agree nor disagree; $3=$ agree $; 4=$ strongly agree). Several items in the subscale were reverse-coded prior to scoring to retain the subscale's positive or negative gradient. Means were calculated for each subscale. Higher scores indicate a greater impact of cancer. Depending upon the respondent's marital/relationship status, skip patterns in the survey guided respondents to one of two separate and conditional subscales consisting of 7 items each that evaluate "Relationship Concerns". Similarly, dependent upon whether or not the respondent reports having children, one of two sets of items were used to evaluate impact related to "Having Children." Internal reliability coefficients (Cronbach's alpha) for each of the seven IOC subscales ranged from 0.70 to 0.90 .

Two overarching Positive Impact and Negative Impact mean scores were also calculated for 17 items suggestive of positive outcomes (Cronbach's alpha $=.80$ ) and 14 items suggestive of negative outcomes (Cronbach's alpha=.90).

\section{Health-related quality of life}


HRQoL was measured by the Medical Outcomes Study Short Form-36 Health Survey (SF36). The SF-36 is a widely-used and well-validated instrument that assesses HRQoL[22] across eight dimensions. Internal reliability coefficients (Cronbach's alpha) ranged from .52.94. HRQoL is also represented by two factor scores: physical health (Physical Component Score [PCS]) and one for mental health (Mental Component Score [MCS]). Raw scores for MCS and PCS were transformed into T-scores ranging from 0 to 100 for purposes of making age-adjusted comparisons. Higher scores represent better QoL.

\section{Psychological distress}

The Brief Symptom Inventory-18 (BSI-18) was used to measure the extent to which a respondent has been bothered by psychological distress symptoms over the past 7 days[23]. Items were measured along a 5-point Likert scale ranging from 0 (not at all) to 4 (extreme). An overall Global Symptom Index (GSI) was calculated. Raw scores for the GSI were converted to age- and sex-adjusted T-scores for comparison to non-patient community norms (mean, 50; standard deviation, 10). Higher scores indicate greater distress. Internal reliability coefficient (Cronbach's alpha) of the GSI was 0.91 . An overall GSI score of $\geq 63$ suggests caseness for distress.

Sociodemographic and clinical data were collected by patient self-report and included sex, race, employment status, educational attainment, marital/relationship status, age at study, age at diagnosis, and years since diagnosis. Surveillance, Epidemiology, and End Results (SEER) codes were used to categorize cancer type and then organize them by severity of disease[24]. 
To approximate severity of disease, three categories were generated for this study based on epidemiological evidence specific to AYA cancer patients: (1) invasive malignancies with expected five-year survival rates greater than $80 \%$ (e.g., Hodgkin lymphoma); (2) malignancies with expected five-year survival rates of 50-80\% (e.g., osteosarcoma); (3) all other malignancies with expected five-year survival rates less than 50\% (e.g., leukemia)[25]. In addition, respondents were asked to report if they had one or more of the following 11 health problems during the past month: shortness of breath; problems with memory, attention, or concentration; frequent or severe stomach pain, pain in your chest (heartburn) or indigestion; ringing in the ears; pain in your joints; weight loss; frequent fevers; lack of sleep or trouble sleeping; frequent tiredness or fatigue; frequent mouth sores that impact your eating and drinking; frequent headaches.

\section{Statistical analyses}

All statistical analyses were performed using SPSS software, version 22.0 (SPSS Inc., Chicago IL).Two-sided $\mathrm{p}$ values of $<0.05$ were considered statistically significant.

Differences in sociodemographic and clinical characteristics between respondents and nonrespondents were evaluated using chi-square and independent t-tests, where appropriate. Independent t-tests were used to compare mean values of IOC subscale scores by sociodemographic and clinical characteristics with two values (e.g. sex, current health problems). ANOVA was used when covariates had more than two values (e.g. type of cancer). Hierarchical linear regression analyses were then performed separately on three outcomes (PCS, MCS and psychological distress) and included only covariates observed to be 
significantly associated $($ at $\mathrm{p}<0.10)$ with at least one of the outcomes. Hierarchical linear regression models analyzed the independent effects of these covariates on outcomes. Then, changes in standardized beta coefficients were evaluated when positive and negative IOC scales were added to the regression models.

\section{Results}

\section{Subjects characteristics}

One hundred seventy-three AYA cancer survivors completed and returned useable surveys (31\% response rate). No significant differences in age at diagnosis, age at study, or time since diagnosis were observed for respondents and non-respondents. Respondents were significantly more likely to be of white race (80\% vs. $70 \%)$ and diagnosed with a hematological disorder (49\% vs. 37\%). Table 1 summarizes demographic and clinical characteristics of respondents.

\section{Correlates Impact of Cancer}

Table 2 summarizes the overarching negative and positive impact of cancer summary scales and Appendix 1 the IOC-AYA subscale scores and differences across potential correlates.

\section{Age at diagnosis}

The older aged group reported a significantly higher negative impact of cancer summary score compared to the younger aged groups, mainly reflected by higher scores on social life and uncertainties, worries and wonders. In addition, the older aged group reported less positive 
impact of cancer on sense of purpose/goals compared to the younger aged groups. The positive impact of cancer summary score did not differ between age groups.

$\operatorname{Sex}$

Female AYAs scored significantly higher on the negative impact of cancer summary scale and the subscales uncertainties, worries and wonders, and cognitive function compared to males. No difference between the sexes was found for the positive impact of cancer summary scale, though female AYAs had a significantly higher score on identity compared to males. Race

Non-white AYAs reported a higher negative impact of cancer on social life compared to White AYA cancer survivors. No differences in negative or positive summary scores were found.

\section{Cancer type}

Significant differences in impact of cancer were observed across cancer type categories, testicular cancer patients reported less uncertainties, worries and wonders compared to leukemia patients. And soft-tissue sarcoma and testicular cancer patients reported less negative impact on cognitive function and overall negative impact compared to hematological cancer patients. Testicular cancer patients reported less positive impact on identity compared to Non-Hodgkin and bone sarcoma patients. No difference was found in the positive impact of cancer summary score.

Severity of disease 
Those with higher disease severity reported higher negative impact of cancer (social life, cognitive function, and negative summary score). No difference in positive impact summary score was found.

Time since diagnosis

Reporting a negative impact of cancer was negatively associated with years since diagnosis, in that the likelihood of reporting negative impact of cancer diminished as AYA survivors moved further in time ( $>5$ years) from their diagnosis. This difference is mainly reflected in the domains social life and uncertainties, worries and wonders.

\section{Educational level and employment status}

Employment status and educational attainment were significantly associated with negative impacts of cancer, with higher scores for those unemployed and with a lower educational level. Being employed was associated with higher positive impact of cancer on sense of purpose/goals and health behavior, the last one was also higher for those with a higher educational attainment.

Partnership status and having children

No significant effects were found for partnership status and having children.

Health problems and distress

Survivors reporting health problems or high levels of psychological distress had statistically higher negative and lower positive impact of cancer scores.

\section{Associations between impact of cancer and HRQoL and distress}

This article is protected by copyright. All rights reserved. 
Three multivariate hierarchical regression models reporting standardized beta coefficients for each outcome (PCS, MCS and psychological distress) were conducted (Table 3).

Occupational/school status, disease severity and current health problems were significantly associated with PCS and maintained significant throughout all models. Negative and positive impact of cancer were not associated with PCS scores, while they were significantly associated with MCS and psychological distress. Age at time diagnosis, sex and educational level were significantly associated with MCS scores in model 1, but these effects were attenuated (even not significant for educational level anymore) once accounting for negative and positive impacts of cancer. Similarly, employment status, educational level and current health problems were significantly associated with psychological distress, but these effects diminished when negative and positive impact were added to the model.

\section{Discussion}

The primary aim of this study was to examine the extent to which negative and positive perceptions of cancer's impact on AYA cancer survivors' lives influences the quality of their lives. Our results reinforce the notion that perceptions are real in their consequences. The standardized beta coefficients for positive and negative subscales reported here suggest that the relative impact of positive and negative perceptions on AYA cancer survivors' HRQoL and psychological distress was greater than the effect of any other demographic or cancerspecific correlate, a finding consistent with studies of cancer survivors of varied ages[12, 2628]. The results highlight that how AYA cancer survivors appraise their cancer experience 
and how they view themselves as cancer patients or survivors and how well they are able to problem-solve and re-engage with goals is associated with how they adapt to the experience.

The variability of negative and positive impact of cancer in AYA cancer survivors suggests that survivor characteristics, inclusive of age, sex, employment status, educational level, cancer type, disease severity, time since diagnosis, current health problems and psychological distress, have unique and specific associations with different aspects of impact of cancer. This finding indicates that some AYA cancer survivors are more in need of programs to reframe perceptions. For example, older AYA cancer survivors reported higher negative impact of cancer, which may have to do with higher work-related and social demands and more responsibilities (partner, children) at time of diagnosis. Educational attainment and occupational status also appeared to be associated with impact of cancer. Not being successful to attain life goals such as finishing school may result in feelings of abnormalcy, problems in social life and more worries. While being successful in getting a job may contribute to survivors feeling like their lives are normal after having had cancer, which is also reflected by the higher scores on 'sense of purpose/goals in life'. Differences in impact of cancer between tumor types might be explained by differences in intensity of treatment, number and kind of debilitating ongoing symptoms and late effects, length of hospital stay and chance of disease recurrence. Furthermore, consistent with prior research, negative impact of cancer decreased over time. This could be explained by the fact that for most cancer survivors who resumed their lives after cancer, the number of reminders of cancer decrease. Those who experience current health problems (potential reminders of cancer[29]) or distress had more negative and 
less positive impact of cancer. These last results suggest that post-treatment symptom and distress management may also be helpful to decrease negative and increase positive impact of cancer. Reducing health problems may also have a direct positive effect on physical HRQoL.

\section{Clinical implications}

Since perceptions are malleable, cognitive behavioral therapy and/or peer support programs may help to reframe negative perceptions and promote positive perceptions, and will thereby potentially enhance well-being outcomes for AYA cancer survivors[8, 30]. Programs and services that offer opportunities for AYAs to tell their stories and share their challenges, struggles, and successes with others have already proven to be powerful interventions that promote the quality of AYAs lives[31]. These opportunities, coming in the form of oncology camps or retreats and social meet-ups may serve as experiences or cues that reinforce positive adaptation and, for some, facilitate post-traumatic growth or thriving - the notion that one's life is renewed, re-normalized, or perhaps even better for having overcome cancer.

\section{Study limitations}

The cross-sectional study design limits the ability to determine direction of causation. For example, we cannot determine whether perceptions of the cancer experience influence or are influenced by HRQoL and psychological distress, or if both are true. Reliance on self-report data of clinical characteristics (e.g. tumor type) and lack of data from medical records or other objective sources (e.g., treatment modalities, history of relapse, metastatic disease, treatmentrelated late effects) also temper our findings, as these conditions may be related to HRQoL 
outcomes. The response rate and inclusion of only a selected group of tumor types (only $41 \%$ of all invasive cancers in the AYA age range were covered, primarily lower risk cancers among higher educated and employed, white survivors) and age range (15-29 years at diagnosis) also limits the generalizability of our findings, although respondents were representative of the entire sample pool in terms of age at diagnosis, age at study, time since diagnosis, and sex. Limited response rate is a common problem in studies involving AYAs[32, 33], partially reflecting the difficulty in locating and recruiting a geographicallymobile young adult population that in most cases is many years beyond therapy and no longer living with their parents. Reporter bias cannot be excluded as cancer survivors may be likely to over report on what they think is important. Longitudinal studies are needed to establish evidence of causality, which could lead to the refinement of psychotherapeutic approaches that will ultimately to enhance HRQoL in AYA cancer survivors. In addition, attention needs to be paid to the management of current health problems and helping AYAs to get back to work or get a job as these factors were strongly associated with physical well-being.

\section{References}

1. Arnett JJ. Emerging adulthood. A theory of development from the late teens through the twenties. Am Psychol 2000; 55: 469-480.

2. Thomas DM, Albritton KH, Ferrari A. Adolescent and young adult oncology: an emerging field. J Clin Oncol 2010; 28: 4781-4782.

3. Zebrack BJ. Psychological, social, and behavioral issues for young adults with cancer. Cancer 2011; 117: 2289-2294.

4. Larouche SS, Chin-Peuckert L. Changes in body image experienced by adolescents with cancer. J Pediatr Oncol Nurs 2006; 23: 200-209.

5. Bolte S, Zebrack B. Sexual issues in special populations: adolescents and young adults. Semin Oncol Nurs 2008; 24: 115-119.

6. Wettergren L, Kent EE, Mitchell SA et al. Cancer negatively impacts on sexual function in adolescents and young adults: The Aya Hope study. Psychooncology 2016. 
7. D'Agostino NM, Penney A, Zebrack B. Providing developmentally appropriate psychosocial care to adolescent and young adult cancer survivors. Cancer 2011; 117: 23292334.

8. Warner EL, Kent EE, Trevino KM et al. Social well-being among adolescents and young adults with cancer: A systematic review. Cancer 2016; 122: 1029-1037.

9. Kwak M, Zebrack BJ, Meeske KA et al. Trajectories of psychological distress in adolescent and young adult patients with cancer: a 1-year longitudinal study. J Clin Oncol 2013; 31: 2160-2166.

10. Quinn GP, Goncalves V, Sehovic I et al. Quality of life in adolescent and young adult cancer patients: a systematic review of the literature. Patient Relat Outcome Meas 2015; 6:

$19-51$.

11. $=$ Bellizzi KM, Smith A, Schmidt S et al. Positive and negative psychosocial impact of being diagnosed with cancer as an adolescent or young adult. Cancer 2012; 118: 5155-5162. 12. Zebrack BJ, Landier W. The perceived impact of cancer on quality of life for posttreatment survivors of childhood cancer. Qual Life Res 2011; 20: 1595-1608.

13. Barakat LP, Alderfer MA, Kazak AE. Posttraumatic growth in adolescent survivors of cancer and their mothers and fathers. J Pediatr Psychol 2006; 31: 413-419.

14. Kuhn T. The Structure of Scientific Revolutions. Chicago: University of Chicago Press 1962.

15. Lazarus RS \& Folkman S. Stress, appraisal, and coping. New York: Springer 1984.

16. Taylor SE. Adjustment to threatening events: A theory of cognitive adaptation. . American Psychologist 1983; 11: 1161-1173.

17. Cagle JG \& Loscalzo M. Using cognitive and behavioral approaches throughout the cancer experience. In Christ G, Messner C, Behar L (ed). Handbook of Oncology Social Work: Psychosocial Care for People with Cancer. New York: Oxford University Press 2015. 18. Husson O, Zebrack BJ. Psychometric Evaluation of an Adolescent and Young Adult (AYA) module of the Impact of Cancer Instrument. J Adolescent Young Adult Oncol 2016; in press.

19. Zebrack B. Developing a new instrument to assess the impact of cancer in young adult survivors of childhood cancer. J Cancer Surviv 2009; 3: 174-180.

20. Zebrack BJ, Ganz PA, Bernaards CA et al. Assessing the impact of cancer: development of a new instrument for long-term survivors. Psychooncology 2006; 15: 407421.

21. Bleyer A, Viny A, Barr RD: Cancer Epidemiology in Older Adolescents and Young Adults 15 to 29 Years: SEER Incidence and Survival, 1975-2000 (NIH Pub. No. 06-5767,). Bethesda: National Cancer Institute; 2006.

22. Ware JE, Snow KK, Kosinski M, et al: SF-36 Health Survey: Manual and Interpretation Guide. Boston, MA, The Health Institute, New England Medical Center, 1993. 23. Derogatis LR. Brief Symptom Inventory 18: Administration, Scoring, and Procedures Manual. Bloomington: Pearson; 2001.

24. Howlader N, Noone AM, Krapcho M, et al: SEER Cancer Statistics Review, 19752008. Bethesda, National Institutes of Health, 2011.

25. Bleyer A. Latest Estimates of Survival Rates of the 24 Most Common Cancers in Adolescent and Young Adult Americans. J Adolesc Young Adult Oncol 2011; 1: 37-42. 
26. Zebrack BJ, Yi J, Petersen L, Ganz PA. The impact of cancer and quality of life for long-term survivors. Psychooncology 2008; 17: 891-900.

27. Smith SK, Crespi CM, Petersen L et al. The impact of cancer and quality of life for post-treatment non-Hodgkin lymphoma survivors. Psychooncology 2010; 19: 1259-1267.

28. Taylor SE. Attributions, beliefs about control, and adjustment to breast cancer. Journal of Personality and Social Psychology 1984; 46: 489-502.

29. Langeveld NE, Grootenhuis MA, Voute PA, de Haan RJ. Posttraumatic stress symptoms in adult survivors of childhood cancer. Pediatr Blood Cancer 2004; 42: 604-610.

30. Yi J, Zebrack B, Kim MA, Cousino M. Posttraumatic Growth Outcomes and Their Correlates Among Young Adult Survivors of Childhood Cancer. J Pediatr Psychol 2015; 40: 981-991.

31. - Sansom-Daly UM, Peate M, Wakefield CE et al. A systematic review of psychological interventions for adolescents and young adults living with chronic illness. Health Psychol 2012; 31: 380-393.

32. Rosenberg AR, Bona K, Wharton CM et al. Adolescent and Young Adult Patient Engagement and Participation in Survey-Based Research: A Report From the "Resilience in Adolescents and Young Adults With Cancer" Study. Pediatr Blood Cancer 2016; 63: 734-736. 33. Harlan LC, Lynch CF, Keegan TH et al. Recruitment and follow-up of adolescent and young adult cancer survivors: the AYA HOPE Study. J Cancer Surviv 2011; 5: 305-314.

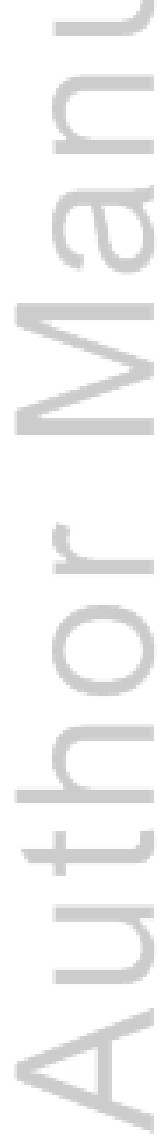


TABLE 1. Sample descriptives

\begin{tabular}{|c|c|}
\hline & $\begin{array}{l}\text { Respondents } \\
\quad(n=173)\end{array}$ \\
\hline Age at time diagnosis (SD;range) & $21.6(4.0 ; 15-29)$ \\
\hline $15-17$ & $36(20.8 \%)$ \\
\hline $18-25$ & $107(61.8 \%)$ \\
\hline $26-29$ & $30(17.3 \%)$ \\
\hline Age at time survey (SD;range) & $27.3(4.3 ; 18-35)$ \\
\hline \multicolumn{2}{|l|}{ Sex } \\
\hline Male & $100(57.8 \%)$ \\
\hline Female & $73(42.2 \%)$ \\
\hline \multicolumn{2}{|l|}{ Race } \\
\hline White & $139(80.3 \%)$ \\
\hline Non-White & $11(6.4 \%)$ \\
\hline Unknown or missing & $23(13.3 \%)$ \\
\hline \multicolumn{2}{|l|}{ Employment Status } \\
\hline Employed & $136(82.4)$ \\
\hline Unemployed & $29(17.6)$ \\
\hline \multicolumn{2}{|l|}{ Education } \\
\hline High School Grad or less & $16(9.8)$ \\
\hline Some College & $43(26.2)$ \\
\hline Associate Degree & $19(11.6)$ \\
\hline College Grad or more & $86(52.4)$ \\
\hline \multicolumn{2}{|l|}{ Partnership Status } \\
\hline No & $78(45.1)$ \\
\hline Yes & $90(52.0)$ \\
\hline \multicolumn{2}{|l|}{ Children } \\
\hline Yes & $37(22.3)$ \\
\hline No & $129(77.2)$ \\
\hline Time since diagnosis (SD;range) & $5.7(2.6 ; 2-10)$ \\
\hline $2-5$ years & $91(52.6 \%)$ \\
\hline$>5$ years & $82(47.4 \%)$ \\
\hline \multicolumn{2}{|l|}{ Cancer type } \\
\hline Hodgkin lymphoma & $59(34.1 \%)$ \\
\hline Non-Hodgkin lymphoma & $26(15.0 \%)$ \\
\hline Leukemia & $32(18.5 \%)$ \\
\hline Testicular & $33(19.1 \%)$ \\
\hline Soft tissue sarcoma & $17(9.8 \%)$ \\
\hline Bone tumors & $5(2.9 \%)$ \\
\hline Rhabdomyosarcoma & $1(0.6 \%)$ \\
\hline \multicolumn{2}{|l|}{ Cancer Survival Rate } \\
\hline $80-100 \%$ & $92(53.2 \%)$ \\
\hline $50-80 \%$ & $48(27.7 \%)$ \\
\hline$<50 \%$ & $33(19.1 \%)$ \\
\hline
\end{tabular}




\section{Health Problem interfere daily}

\section{activities}

No Health problem

$90(52.6)$

Problem but no interference

$8(4.7)$

mild interference

severe interference

Health Problem other than cancer

Yes

$90(55.2)$

No 73(44.8)

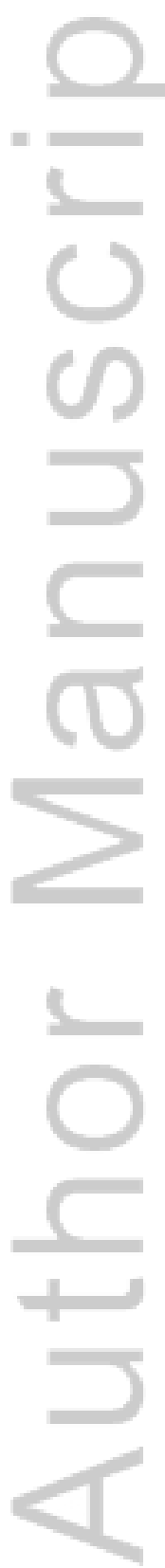

This article is protected by copyright. All rights reserved. 
TABLE 2. Bivariate comparisons of mean overarching IOC-AYA positive and negative summary subscales by selected independent variables

\begin{tabular}{|c|c|c|}
\hline & $\begin{array}{l}\text { Negative impact } \\
\text { scale }\end{array}$ & $\begin{array}{l}\text { Positive impact } \\
\text { scale }\end{array}$ \\
\hline All respondents & $1.5(0.8)$ & $2.9(0.5)$ \\
\hline $\begin{array}{l}\text { Age at time diagnosis } \\
15-17 \\
18-25 \\
26-29 \\
p \text {-value }\end{array}$ & $\begin{array}{l}1.5(0.9) \\
1.4(0.8) \\
1.8(0.9) \\
0.04\end{array}$ & $\begin{array}{l}2.9(0.4) \\
2.9(0.5) \\
2.8(0.6) \\
0.51 \\
\end{array}$ \\
\hline $\begin{array}{l}\text { Sex } \\
\text { Female } \\
\text { Male } \\
\text { p-value }\end{array}$ & $\begin{array}{l}1.6(0.8) \\
1.3(0.9) \\
0.03\end{array}$ & $\begin{array}{l}2.9(0.5) \\
2.8(0.5) \\
0.20\end{array}$ \\
\hline $\begin{array}{l}\text { Race } \\
\text { White } \\
\text { Non-White } \\
p \text {-value }\end{array}$ & $\begin{array}{l}1.4(0.9) \\
1.7(0.5) \\
0.32\end{array}$ & $\begin{array}{l}2.9(0.5) \\
2.9(0.4) \\
0.75\end{array}$ \\
\hline $\begin{array}{l}\text { Employment status } \\
\text { Unemployed } \\
\text { Employed } \\
p \text {-value }\end{array}$ & $\begin{array}{l}1.8(0.8) \\
1.4(0.8) \\
0.02\end{array}$ & $\begin{array}{l}2.7(0.6) \\
2.8(0.5) \\
0.05\end{array}$ \\
\hline $\begin{array}{l}\text { Education } \\
\text { High school or less } \\
\text { Some college } \\
\text { Associate degree } \\
\text { College grad or more } \\
p \text {-value }\end{array}$ & $\begin{array}{l}1.7(0.9) \\
1.9(1.0) \\
1.3(0.8) \\
1.3(0.7) \\
0.001 \\
\end{array}$ & $\begin{array}{l}2.6(0.6) \\
2.8(0.5) \\
2.9(0.6) \\
2.9(0.4) \\
0.05\end{array}$ \\
\hline $\begin{array}{l}\text { Partner status } \\
\text { No } \\
\text { Yes } \\
\text { p-value }\end{array}$ & $\begin{array}{l}1.5(0.9) \\
1.4(0.8) \\
0.46\end{array}$ & $\begin{array}{l}2.8(0.6) \\
2.9(0.4) \\
0.18\end{array}$ \\
\hline $\begin{array}{l}\text { Child } \\
\text { Yes } \\
\text { No } \\
\text { p-value }\end{array}$ & $\begin{array}{l}1.4(0.8) \\
1.5(0.8) \\
0.59\end{array}$ & $\begin{array}{l}3.0(0.5) \\
2.8(0.5) \\
0.14\end{array}$ \\
\hline $\begin{array}{l}\text { Cancer type } \\
\text { Hodgkin } \\
\text { Non-Hodgkin } \\
\text { Leukemia } \\
\text { Testicular } \\
\text { Soft tissue sarcoma } \\
\text { Bone tumors } \\
\text { p-value }\end{array}$ & $\begin{array}{l}1.5(0.8) \\
1.6(0.9) \\
1.9(0.8) \\
1.1(0.7) \\
1.1(0.7) \\
1.4(0.8) \\
0.001 \\
\end{array}$ & $\begin{array}{l}2.9(0.5) \\
2.9(0.6) \\
2.8(0.4) \\
2.8(0.5) \\
3.0(0.4) \\
3.2(0.6) \\
0.36 \\
\end{array}$ \\
\hline $\begin{array}{l}\text { Cancer survival rate } \\
80-100 \% \\
50-80 \% \\
<50 \% \\
p \text {-value }\end{array}$ & $\begin{array}{l}1.4(0.8) \\
1.4(0.9) \\
1.8(0.8) \\
0.01\end{array}$ & $\begin{array}{l}2.9(0.5) \\
3.0(0.6) \\
2.8(0.4) \\
0.24\end{array}$ \\
\hline $\begin{array}{l}\text { Time since diagnosis } \\
2-5 \text { years } \\
>5 \text { years } \\
\text { p-value }\end{array}$ & $\begin{array}{l}1.6(0.9) \\
1.3(0.8) \\
0.005\end{array}$ & $\begin{array}{l}2.9(0.6) \\
2.9(0.4) \\
0.77\end{array}$ \\
\hline Report current health & & \\
\hline
\end{tabular}




\begin{tabular}{|l|l|l|}
\hline problems & & \\
Yes & $1.8(0.9)$ & $2.7(0.5)$ \\
No & $1.2(0.7)$ & $3.0(0.5)$ \\
$p$-value & $<0.001$ & $<0.001$ \\
\hline Caseness for distress & & \\
from BSI-18 & & \\
Yes & $2.3(0.8)$ & $2.5(0.5)$ \\
No & $1.3(0.7)$ & $3.0(0.5)$ \\
$p$-value & $<0.001$ & $<0.001$ \\
\hline
\end{tabular}

This article is protected by copyright. All rights reserved. 
TABLE 3. Multivariate hierarchical linear regression analyses of the association between IOC-AYA summary scales and HRQoL and psychological distress (standardized betas are presented)

\begin{tabular}{|c|c|c|c|c|c|c|c|c|c|}
\hline & \multicolumn{3}{|l|}{ PCS } & \multicolumn{3}{|l|}{ MCS } & \multicolumn{3}{|c|}{ Psychological distress } \\
\hline & $\begin{array}{l}\text { Model } \\
1\end{array}$ & $\begin{array}{l}\text { Model } \\
2\end{array}$ & $\begin{array}{l}\text { Model } \\
\mathbf{3} \\
\end{array}$ & $\begin{array}{l}\text { Model } \\
1\end{array}$ & $\begin{array}{l}\text { Model } \\
2 \\
\end{array}$ & Model 3 & $\begin{array}{l}\text { Model } \\
1\end{array}$ & Model 2 & Model 3 \\
\hline $\begin{array}{l}\text { Age } \\
15-17 \\
18-25 \\
>26 \\
\end{array}$ & $\begin{array}{l}-0.13 \\
-0.11 \\
\text { ref }\end{array}$ & $\begin{array}{l}-0.15 \\
-0.13 \\
\text { Ref }\end{array}$ & $\begin{array}{l}-0.15 \\
-0.12 \\
\text { Ref }\end{array}$ & $\begin{array}{l}0.22^{*} \\
0.30^{* *} \\
\operatorname{Ref}\end{array}$ & $\begin{array}{l}0.08 \\
0.16 \\
\text { Ref }\end{array}$ & $\begin{array}{l}0.05 \\
0.19^{*} \\
\text { Ref }\end{array}$ & $\begin{array}{l}-0.09 \\
-0.13 \\
\text { Ref }\end{array}$ & $\begin{array}{l}0.05 \\
0.01 \\
\text { Ref }\end{array}$ & $\begin{array}{l}0.07 \\
-0.01 \\
\text { Ref }\end{array}$ \\
\hline $\begin{array}{l}\text { Sex } \\
\text { Female } \\
\text { Male }\end{array}$ & $\begin{array}{l}-0.02 \\
\text { ref }\end{array}$ & $\begin{array}{l}-0.01 \\
\text { Ref }\end{array}$ & $\begin{array}{l}-0.01 \\
\text { Ref }\end{array}$ & $\begin{array}{l}-0.18^{*} \\
\operatorname{Ref}\end{array}$ & $\begin{array}{l}-0.07 \\
\text { Ref }\end{array}$ & $\begin{array}{l}-0.13^{*} \\
\text { Ref }\end{array}$ & $\begin{array}{l}0.07 \\
\text { Ref }\end{array}$ & $\begin{array}{l}-0.04 \\
\text { Ref }\end{array}$ & $\begin{array}{l}0.01 \\
\text { Ref }\end{array}$ \\
\hline $\begin{array}{l}\text { Race } \\
\text { White } \\
\text { Non-white }\end{array}$ & $\begin{array}{l}\text { Ref } \\
-0.01\end{array}$ & $\begin{array}{l}\text { Ref } \\
-0.01\end{array}$ & $\begin{array}{l}\text { Ref } \\
-0.01\end{array}$ & $\begin{array}{l}\text { Ref } \\
-0.01\end{array}$ & \begin{tabular}{|l} 
Ref \\
0.03 \\
\end{tabular} & $\begin{array}{l}\text { Ref } \\
0.01\end{array}$ & $\begin{array}{l}\text { Ref } \\
-0.02\end{array}$ & $\begin{array}{l}\text { Ref } \\
-0.03\end{array}$ & $\begin{array}{l}\text { Ref } \\
-0.01\end{array}$ \\
\hline $\begin{array}{l}\text { Partnership status } \\
\text { No } \\
\text { Yes }\end{array}$ & $\begin{array}{l}\text { Ref } \\
-0.09\end{array}$ & $\begin{array}{l}\text { Ref } \\
-0.10\end{array}$ & $\begin{array}{l}\text { Ref } \\
-0.10\end{array}$ & $\begin{array}{l}\text { Ref } \\
0.15\end{array}$ & $\begin{array}{l}\text { Ref } \\
0.09\end{array}$ & $\begin{array}{l}\text { Ref } \\
0.04\end{array}$ & $\begin{array}{l}\text { Ref } \\
-0.05\end{array}$ & $\begin{array}{l}\text { Ref } \\
-0.01\end{array}$ & $\begin{array}{l}\text { Ref } \\
0.02\end{array}$ \\
\hline $\begin{array}{l}\text { Employment status } \\
\text { Unemployed } \\
\text { Employed }\end{array}$ & $\begin{array}{l}-0.25^{* *} \\
\text { ref }\end{array}$ & $\begin{array}{l}-0.25^{* *} \\
\text { Ref }\end{array}$ & $\begin{array}{l}-0.25^{* *} \\
\text { Ref }\end{array}$ & $\begin{array}{l}-0.16 \\
\text { Ref }\end{array}$ & $\begin{array}{l}-0.14 \\
\text { Ref }\end{array}$ & $\begin{array}{l}-0.11 \\
\text { Ref }\end{array}$ & $\begin{array}{l}0.15^{*} \\
\text { Ref }\end{array}$ & $\begin{array}{l}0.14^{*} \\
\text { Ref }\end{array}$ & $\begin{array}{l}0.12 * \\
\text { Ref }\end{array}$ \\
\hline $\begin{array}{l}\text { Education } \\
\text { Some college or less } \\
\text { Associate degree or } \\
\text { higher }\end{array}$ & $\begin{array}{l}\text { ref } \\
0.14^{*}\end{array}$ & $\begin{array}{l}\text { Ref } \\
0.13\end{array}$ & $\begin{array}{l}\text { Ref } \\
0.13\end{array}$ & $\begin{array}{l}\text { Ref } \\
0.18^{*}\end{array}$ & $\begin{array}{l}\text { Ref } \\
0.04\end{array}$ & $\begin{array}{l}\text { Ref } \\
0.03\end{array}$ & $\begin{array}{l}\text { Ref } \\
-0.26^{* *}\end{array}$ & $\begin{array}{l}\text { Ref } \\
-0.14^{*}\end{array}$ & $\begin{array}{l}\text { Ref } \\
-0.14 *\end{array}$ \\
\hline $\begin{array}{l}\text { Cancer survival rate } \\
80-100 \% \\
50-80 \% \\
<50 \% \\
\end{array}$ & $\begin{array}{l}\text { Ref } \\
-0.11 \\
-0.18^{*}\end{array}$ & $\begin{array}{l}\text { Ref } \\
-0.11 \\
-0.18^{*}\end{array}$ & $\begin{array}{l}\text { Ref } \\
-0.11 \\
-0.18 *\end{array}$ & $\begin{array}{l}\text { Ref } \\
0.10 \\
0.08\end{array}$ & $\begin{array}{l}\text { Ref } \\
0.12 \\
0.13\end{array}$ & $\begin{array}{l}\text { Ref } \\
0.07 \\
0.10\end{array}$ & $\begin{array}{l}\text { Ref } \\
-0.03 \\
-0.01 \\
\end{array}$ & $\begin{array}{l}\text { Ref } \\
-0.03 \\
-0.06 \\
\end{array}$ & $\begin{array}{l}\text { Ref } \\
0.01 \\
-0.04\end{array}$ \\
\hline $\begin{array}{l}\text { Report current health } \\
\text { problems } \\
\text { Yes } \\
\text { No }\end{array}$ & $\begin{array}{l}-0.34 * * \\
\text { ref }\end{array}$ & $\begin{array}{l}-0.33^{* *} \\
\operatorname{Ref}\end{array}$ & $\begin{array}{l}-0.33^{* *} \\
\text { Ref }\end{array}$ & $\begin{array}{l}-0.09 \\
\text { Ref }\end{array}$ & $\begin{array}{l}0.01 \\
\text { Ref }\end{array}$ & $\begin{array}{l}0.07 \\
\text { Ref }\end{array}$ & $\begin{array}{l}0.24 * * \\
\operatorname{Ref}\end{array}$ & $\begin{array}{l}0.12^{*} \\
\text { Ref }\end{array}$ & $\begin{array}{l}0.08 \\
\text { Ref }\end{array}$ \\
\hline Negative impact scale & & -0.06 & -0.05 & & $-0.54 * *$ & $-0.39 * *$ & & $0.55 * *$ & $0.45 * *$ \\
\hline Positive impact scale & & & 0.03 & & & $0.38 * *$ & & & $-0.26^{* *}$ \\
\hline Model F value & 8.56 & 7.92 & 7.32 & 3.76 & 8.46 & 11.95 & 6.58 & 14.28 & 16.09 \\
\hline $\begin{array}{l}\begin{array}{l}\text { Overall model } \\
\text { significance }\end{array} \\
\end{array}$ & $<0.001$ & $<0.001$ & $<0.001$ & $<0.001$ & $<0.001$ & $<0.001$ & $<0.001$ & $<0.001$ & $<0.001$ \\
\hline Adjusted R2 & 0.42 & 0.42 & 0.42 & 0.24 & 0.44 & 0.55 & 0.36 & 0.57 & 0.62 \\
\hline Change in R2 & & 0.0 & 0.0 & & $0.20 * *$ & $0.11 * *$ & & $0.21 * *$ & $0.05 * *$ \\
\hline
\end{tabular}

PCS= Physical Component Score; MCS= Mental Component Score

$*_{\mathrm{p}}=<0.05$

$* * \mathrm{p}=<0.01$ 